\title{
MANAJEMEN OPERASIONAL PELABUHAN PENYEBERANGAN BATULICIN - TANJUNG SERDANG PROVINSI KALIMANTAN SELATAN
}

\section{OPERATIONAL MANAGEMENT OF BATULICIN FERRY PORT - TANJUNG SERDANG, SOUTH KALIMANTAN PROVINCE}

\author{
Hudan Rahmani ${ }^{1 *}$, Noor Jasmani ${ }^{2}$, Aminullah ${ }^{3}$, Hendra Cahyadi ${ }^{4}$ \\ ${ }^{1,2,3}$ Dosen, Program Studi Teknik Sipil, Fakultas Teknik, Universitas Nahdlatul Ulama Kalsel \\ ${ }^{4}$ Dosen, Program Studi Teknik Sipil, Fakultas Teknik, Universitas Islam Kalimantan \\ *Korespondensi: uwa.hudan58@gmail.com
}

\begin{abstract}
ABSTRAK
Pelabuhan penyeberangan Batulicin di Tanah Bumbu dan penyeberangan Tanjung Serdang di Kotabaru kabupaten Pulau Laut mempunyai peranan yang sangat penting bagi transportasi dalam memperlancar arus barang dan manusia sebagai rangkaian dari Jalan Lintas Kalimantan Poros Selatan yang menghubungkan antara kota Banjarmasin dan semua kota di provinsi Kalimantan Selatan maupun kota-kota di pulau Kalimantan ke Kotabaru kabupaten Tanah Laut. Dengan adanya perkembangan ekonomi di sekitar pertambangan batubara, perkebunan dan pariwisata di Kalimantan Selatan diperkirakan kebutuhan jasa transportasi dari tahun ke tahun selalu meningkat. Untuk mengantisipasi kondisi tersebut, maka sistem angkutan darat dan penyeberangan diperlukan standar kinerja yang optimal. Penelitian ini dilakukan di pelabuhan penyeberangan lintas Batulicin - Tanjung Serdang dengan mengambil studi kasus di pelabuhan ferry Batulicin dan Tanjung Serdang. Tujuan dari penelitian ini untuk mendapatkan pemecahan atas masalah optimasi sistem operasi pelabuhan Batulicin apakah diperlukan penambahan kapal akibat adanya antrian yang cukup panjang dari mobil penumpang dan barang yang akan menyeberang dari Batulicin ke Kotabaru atau sebaliknya. Data yang dikumpulkan meliputi kinerja sistem penyeberangan, pengambilan data dilakukan pada tanggal 20 Desember sampai dengan 24 Desember 2021. Analisa data berdasarkan konsep biaya gabungan, antara biaya waktu tunggu kendaraan dan biaya operasi kapal, dengan jumlah kapal. Dari hasil pembahasan dapat disimpulkan bahwa manajemen operasional dalam bentuk sistem kinerja yang optimal diperlukan jumlah kapal sebanyak 4 buah dengan acuan biaya gabungan yang minimal.
\end{abstract}

Kata Kunci: penyeberangan, panjang antrian, biaya waktu tunggu, jumlah kapal

\begin{abstract}
The Batulicin ferry port in Tanah Bumbu and the Tanjung Serdang crossing in Kotabaru, Pulau Laut district, has a very important role for transportation in facilitating the flow of goods and people as a series of the South Kalimantan Axis Cross Road that connects the city of Banjarmasin and all cities in South Kalimantan province and the city. -cities on the island of Kalimantan to Kotabaru, Tanah Laut district. With the economic development around coal mining, plantations and tourism in South Kalimantan, it is estimated that the need for transportation services from year to year always increases. To anticipate these conditions, the land transportation system and crossing required optimal performance standards. This research was conducted at
\end{abstract}


the Batulicin - Tanjung Serdang crossing by taking case studies at the Batulicin and Tanjung Serdang ferry ports. The purpose of this study is to find a solution to the problem of optimizing the Batulicin port operating system whether additional ships are needed due to the long queue of passenger cars and goods that will cross from Batulicin to Kotabaru or vice versa. The data collected includes the performance of the crossing system, data retrieval is carried out on December 20 to December 24, 2021. Data analysis is based on the concept of combined costs, between vehicle waiting time costs and ship operating costs, with the number of ships. From the results of the discussion, it can be concluded that operational management in the form of an optimal performance system requires 4 ships with a minimum combined cost reference.

Keywords: ferry port, queue Length, waiting time fee, number of ships

\section{PENDAHULUAN}

\section{Latar Belakang}

Pelabuhan penyeberangan Batulicin merupakan rangkaian Jalan Lintas Kalimantan Poros Selatan di provinsi Kalimantan Selatan, arus lalu lintas yang menyeberang menuju atau meninggalkan kota ini sangat tinggi, hal ini disebabkan antara lain tingginya kegiatan pada sektor pariwisata, perdagangan, pertambangan dan kegiatan lainnya. Hal ini tampak pada antrian kendaraan yang akan menyeberang di pelabuhan penyeberangan Batulicin - Tanjung Serdang akhir minggu dan hari libur nasional.

Prasarana di pelabuhan Batulicin terdiri dari 1 (satu) dermaga (pontoon dan moveable bridge) sedangkan Tanjung Serdang 1 (satu) dermaga (pontoon dan moveable bridge), sarana untuk penyeberangan dioperasikan 3 kapal.

Dengan adanya keterbatasan tersebut maka arus kendaraan darat tidak bisa langsung menyeberang, sehingga ada antrian dan waktu tunggu yang mengakibatkan bertambahnya biaya operasi kendaraan dan biaya waktu tunggu penumpang. Mengingat sangat pentingnya pelabuhan penyeberangan Batulicin - Tanjung Serdang untuk melayani transportasi ke kota-kota tujuan maka diupayakan penggunaan fasilitas penyeberangan yang ada secara optimal untuk memberikan pelayanan jasa angkutan. Suatu ketika sistem akan jenuh sehingga perlu adanya upaya manajemen operasional peningkatan pelabuhan penyeberangan Batulicin - Tanjung Serdang.

\section{Tujuan Penelitian}

Tujuan penelitian ini adalah:
a. Memanajemen jumlah kendaraan yang antriannya cukup panjang.
b. Menentukan optimasi jumlah kapal
c. Rekomendasi jumlah dermaga yang ideal.

\section{TINJAUAN PUSTAKA}

\section{Pengertian Transportasi}

Kebutuhan transportasi sebagai hasil interaksi antara aktivitas sosial dan ekonomi yang tersebar di dalam ruang dan tata guna lahan, sehingga dengan adanya penyebaran aktivitas dan pola interaksi akan menimbulkan permasalahan transportasi yang sangat beragam dan banyak faktor yang harus dipertimbangkan (Kanafani Adip, 1983).

Transportasi untuk orang atau barang umumnya tidak dilakukan hanya untuk kegiatan itu saja, tetapi untuk tujuan lainnya sehingga kebutuhan transportasi dapat disebut kebutuhan ikatan (derived demand) yang berasal dari kebutuhan suatu komoditas atau pelayanan (Morlok, 1985).

\section{Pendekatan Sistem Transportasi}

Sistem transportasi adalah gabungan dari beberapa komponen yang saling terkait dan sering mempengaruhi hingga mencapai suatu kondisi. Untuk memahami dan mendapatkan alternatif pemecahan masalah perlu dilakukan pendekatan secara sistem transportasi dalam bentuk sistem transportasi makro yang terdiri dari beberapa transportasi mikro yang saling terkait (Tamin, 1995)

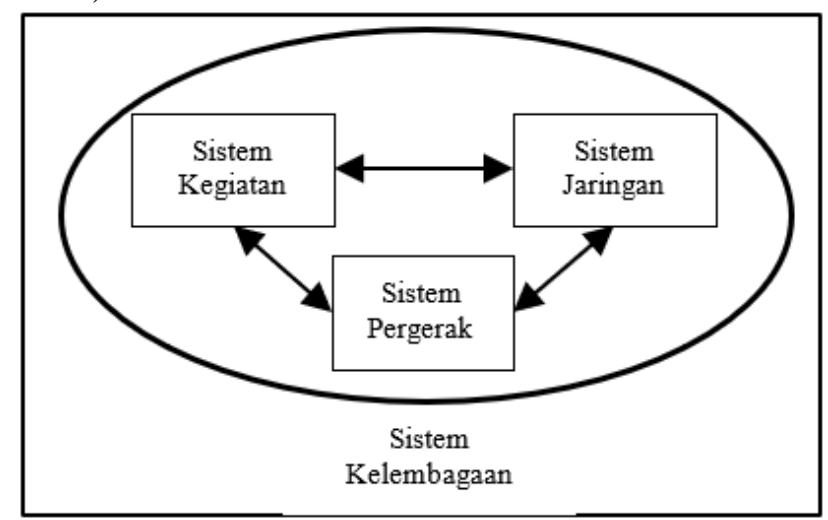

Gambar 1 Sistem Transportasi Makro 


\section{Pengertian Angkutan Penyeberangan}

Angkutan penyeberangan adalah salah satu bagian transportasi air yang menghubungkan dua ujung jalan raya yang dipisahkan sungai besar atau selat yang tidak begitu lebar. Penyediaan sarana dan prasarana transportasi laut dan penyeberangan harus dapat mengatasi kebutuhan permintaan akan jasa transportasi secara efektif dan efisien (Nasution, HMN, 1996).

Fasilitas dermaga dan kapal ferry merupakan jembatan terapung yang diharapkan dapat dan mampu melayani arus lalu lintas yang akan menyeberang.

\section{Sistem Penyeberangan}

Secara umum sistem penyeberangan terdiri dari fasilitas infrastruktur yang dibangun untuk menunjang kegiatan penyeberangan sehingga dapat memberikan pelayanan yang optimal kepada masyarakat pengguna jasa yang membutuhkan.

\section{Elemen Sistem Penyeberangan}

1. Dermaga/Pelabuhan

2. Jembatan Bergerak (moveable bridge)

3. Lapangan Parkir

4. Terminal Penumpang

5. Kapal Penyeberangan (ferry)

6. Jadwal Penyeberangan

\section{Jadwal Penyeberangan}

Jadwal penyeberangan adalah daftar terperinci mengenai rencana operasi penyeberangan dalam waktu rentang tertentu. Sistem penyeberangan kapal ferry umumnya menempuh jarak pendek dan kegiatannya bolak-balik, sehingga jadwal keberangkatan dan kedatangan dapat ditentukan relatif tetap. Keuntungan dari jadwal yang tetap ini adalah para pemakai jasa angkutan penyeberangan memperoleh kepastian untuk melakukan perjalanan dengan menggunakan angkutan penyeberangan dan dapat mencapai tujuan tepat waktu.

\section{Teori Antrian}

Teori antrian bukan merupakan teknik optimasi tetapi sebagai alat analistis yang akan memberikan informasi yang efektif mengenai suatu permasalahan (Siagian, 1987; Nurhayati, 1986).

\section{Sistem Antrian}

Sistem ini terbentuk karena adanya kedatangan pengguna jasa untuk memperoleh pelayanan pada sarana penyeberangan yang ada. Pengguna jasa ini harus menunggu dan membentuk antrian hingga tiba gilirannya untuk dilayani dan setelah selesai dilayani, maka pengguna jasa ini sudah keluar dari sistem.

Penggunaan pengguna jasa (sumber masukan) karakteristik yang perlu diketahui adalah jumlah pengguna jasa yang membutuhkan pelayanan per satuan waktu dan jumlah seluruh pengguna jasa potensial. Pengguna jasa ini diasumsikan terbatas atau tidak terbatas dan pola kedatangannya mengikuti distribusi poisson dan waktu pelayanan mengikuti distribusi eksponensial negatif. Antrian ditandai oleh jumlah pengguna jasa yang diperbolehkan atau yang dapat ditampung. Waktu di dalam antrian adalah waktu yang mulai pengguna jasa datang dalam antrian sampai siap untuk dilayani.

\section{Biaya Operasional Kendaraan (BOK) Waktu Menunggu (PT. Jasa Marga)}

Biaya Kendaraan/Biaya Bunga Bank per Jam (I)

$$
\begin{aligned}
& I=\frac{(E C-S C) \cdot D}{W h} \\
& D=\frac{R(1+R)^{N}}{(1+R) N-1}
\end{aligned}
$$

Dimana:

EC = Nilai ekonomi mobil pribadi

$\mathrm{SC} \quad=$ Nilai sisa (10\% EC)

$\mathrm{R}=$ Suku bunga bank

$\mathrm{N} \quad=$ Umur ekonomis

$\mathrm{D}=$ Faktor pengembalian modal

Wh = Jam kerja efektif

\section{Nilai Waktu Tunggu}

Nilai waktu per jam untuk penumpang menurut PT. Jasa Marga dapat dikategorikan berdasarkan waktu perjalanan yaitu bisnis dan non bisnis. Untuk perjalanan bisnis nilai waktu diasumsikan senilai dengan income per kapita dan nilai perjalanan non bisnis ditetapkan $25 \%$ dari nilai perjalanan bisnis.

Sedangkan pendapatan orang yang memiliki mobil diasumsikan 5 kali income per kapita. Waktu kerja efektif (Wh) dalam satu tahun ditetapkan 2100 jam.

Nilai waktu (bisnis):

$$
\mathrm{NW}=\frac{\text { Income per Kapits }}{\text { Wh }}
$$

Nilai waktu $($ non bisnis $)=5 \times 25 \% \times \mathrm{NW}$ 
Manajemen Operasional.., Hudan Rahmani ${ }^{(1)}$, Noor Jasmani ${ }^{(2)}$, Aminullah $^{(3)}$, Hendra Cahyadi ${ }^{(4)}$

$\begin{array}{ll}\text { Jumlah penumpang } & \begin{array}{c}\text { rata-rata }\left(\mathrm{X}^{\prime}\right)=3,3 \\ \text { orang/penumpang }\end{array} \\ & =\left(\mathrm{X}^{\prime}\right) \times \mathrm{NW} \text { non bisnis } \\ \text { Jumlah NW (non bisnis) } & =\mathrm{I}+\mathrm{NW} \text { non bisnis }\end{array}$

\section{Sistem Operasi Optimum}

Dalam angkutan penyeberangan sistem operasi optimum akan didapat berdasarkan biaya gabungan minimum, yaitu: gabungan biaya operasi kapal dan biaya tunggu kendaraan yang diakibatkan oleh sistem pelayanan yang ada. Prinsip ini didasarkan konsep dengan meningkatkan jumlah pelayanan akan berakibat penurunan waktu tunggu kendaraan dan sebaliknya. Selanjutnya kedua komponen tersebut dikonversikan ke dalam nilai ekonomi/cost (Kodoatie, Robert J, 1997).

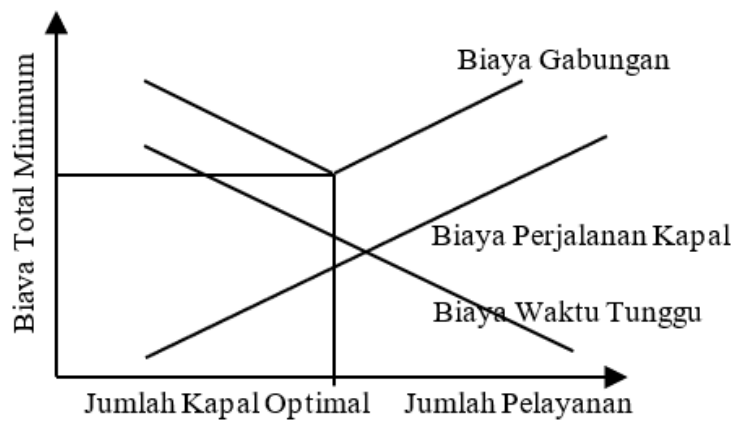

Gambar 2. Sistem Pelayanan Optimum

\section{Proses Penyeberangan}

Kegiatan penyeberangan di pelabuhan Batulicin dengan pelayanan dan fasilitas yang ada seperti areal kedatangan (tempat menunggu kendaraan), prasarana pelayanan (dermaga) dan sarana pelayanan (kapal ferry), kendaraan bermotor roda empat seperti truck, bus dan mobil penumpang atau pribadi, sedangkan sepeda motor dan orang tidak diperhitungkan karena pada umumnya tidak memerlukan pengaturan khusus dan diasumsikan tidak mempengaruhi terhadap lama waktu bongkar dan muat.

Proses pelayanan terjadi pada saat kendaraan antri masuk ke dalam kapal selama headway waktu keberangkatan kapal yang ditentukan.

\section{Ukuran Operasi Sistem Penyeberangan}

Dalam mengoperasikan sistem untuk jenis transportasi tertentu, maka variabel-variabel yang membentuk model harus mempunyai hubungan yang erat agar dapat berfungsi dengan baik. Dalam kondisi ini hubungan antara kapasitas total, headway keberangkatan kapal, jumlah keberangkatan dan kapasitas kapal adalah sebagai berikut:

$$
\mathrm{Qc}=\mathrm{Qk} \times \mathrm{Jk}=\mathrm{Qk} \times \frac{144 \mathrm{C}}{\mathrm{hw}}
$$

Dimana:

Qc = Kapasitas total dalam satu hari (unit kendaraan)

$\mathrm{Qk}=$ Kapasitas kapal rencana (unit kendaraan)

hw = Headway waktu keberangkatan kapal (menit)

$\mathrm{Jk}=$ Jumlah keberangkatan kapal

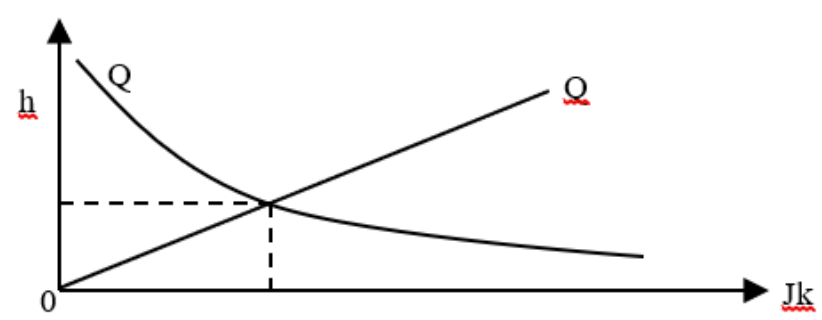

Gambar 3. Keberangkatan, Headway, Kapasitas Kapal dan Kapasitas Sistem

Dihubungkan dengan kebutuhan kapal, maka:

Dimana:

$$
\mathrm{N}=\frac{\mathrm{DJ} \times \mathrm{Tc}}{\mathrm{Hw}}-\frac{\mathrm{D} \times \mathrm{Tc}_{\mathrm{c}}}{\mathrm{hw} \mathrm{x}}=\frac{\mathrm{Tc}}{\mathrm{hw}}
$$

$\mathrm{N}=$ Jumlah kapal

$\mathrm{JD}=$ Jumlah dermaga

$\mathrm{Tc}=$ Waktu siklus kapal $=2(\mathrm{~T} 1+\mathrm{Ts}+\mathrm{Tp})$

$\mathrm{Hw}=$ Headway dermaga

hw $=$ Headway keberangkatan kapal

$\mathrm{Vv}=$ Jumlah kedatangan kendaraan

Sehingga: $N=\frac{2\left(T 1 \times T_{s} \times T_{p}\right.}{h w}$

Jumlah keberangkatan kapal $\quad \mathrm{Jk}=\frac{\mathrm{Vv}}{\mathrm{Qv}}($ trip/jam)

Headway kapal

Jumlah dermaga

$\mathrm{Hw}=\frac{1}{\pi}$ (trip/jam)

$\mathrm{JD}=\stackrel{\mathrm{Tc}}{h \mathrm{ww}}($ trip/jam $)$

\section{Waktu Tunggu Kendaraan}

Apabila headway kapal tidak teratur, waktu tunggu rata-rata kendaraan pada setiap keberangkatan adalah setengah dari interval headway kapal sebelum keberangkatan itu. Jumlah kendaraan yang diharapkan ada akan proporsional terhadap periode itu, sehingga tingkat kedatangan kendaraan rata-rata $\lambda$, maka waktu total untuk keberangkatan I (dijumlahkan untuk semua kendaraan) adalah: $1 / 2\left(t_{i}-t_{i-1}\right) \lambda\left(t_{i}-t_{i-1}\right)=1 / 2 \lambda\left(t_{i}-t_{i-1}\right) 2$ 
$\mathrm{Wt}=\sum_{\mathrm{i}-1}^{\mathrm{n}} \times 1 / 2 \lambda\left(\mathrm{t}_{\mathrm{i}}-\mathrm{t}_{\mathrm{i}-1}\right) 2$

Jumlah total kendaraan yang datang adalah:

$\mathrm{Qt}=\lambda\left(\mathrm{t}_{\mathrm{n}}-\mathrm{t}_{\mathrm{o}}\right)$

Jadi waktu tunggu kendaraan rata-rata adalah:

$$
\begin{aligned}
& \mathrm{Wr}=\frac{\mathrm{Wt}}{\mathrm{Qt}}=\frac{1}{2\left(\mathrm{t}_{n}-\mathrm{t}_{0}\right)} \quad \sum_{\mathrm{i}-1}^{\mathrm{n}} \quad 1 / 2 \quad \lambda\left(\mathrm{t}_{\mathrm{i}}-\mathrm{t}_{\mathrm{i}-1}\right) 2 \\
& =\frac{1}{2\left(t_{n}-t_{0}\right)} \quad \sum_{i-1}^{n} \quad \text { (hi) } 2
\end{aligned}
$$

Dimana:

ti $=$ Waktu keberangkatan ke I

ti-1 = Waktu keberangkatan sebelumnya (i-1)

$\lambda=$ Tingkat kedatangan kendaraan rata-rata/satuan waktu

hi = Headway waktu keberangkatan kapal (menit)

$\mathrm{i}=1,2,3, \ldots \mathrm{n}$

to $=$ Waktu dimana kendaraan mulai tiba

$\mathrm{Wt}=$ Waktu tunggu total kendaraan (menit)

$\mathrm{Qt}=$ Jumlah total kedatangan kendaraan (unit)

$\mathrm{Wr}=$ Waktu rata-rata kendaraan (menit)

Perhitungan Waktu Kendaraan Roda Empat

$\mathrm{Q}=$ Jumlah antrian

$\mathrm{Hk}=$ Headway kapal
$\mathrm{Vv}=$ Frekuensi kedatangan kendaraan roda 4

$\mathrm{Tt}=$ Waktu tunggu total

$\mathrm{Tt}=(0+\mathrm{Hk}) \cdot \frac{\mathrm{Q}}{2}$

$\mathrm{Tt}=(0+\mathrm{Hk}) \cdot \frac{\text { Hk } \cdot \mathrm{V}_{\mathrm{r}}}{2}$

$\mathrm{Q}=\mathrm{Hk} \times \mathrm{Vv}_{\mathrm{v}}$

$\mathrm{Tt}=1 / 2 \mathrm{Vv} . \mathrm{Hk} 2$

Biaya Waktu Penyelenggaraan

Biaya yang harus ditanggung oleh pengguna jasa sebagai opportunity cost yang hilang akibat dari tertundanya pelayanan yang dibutuhkan.

\section{METODE}

Program Kerja Penelitian dengan judul: Studi Optimasi Kinerja Pelabuhan Penyeberangan Batulicin - Tanjung Serdang provinsi Kalimantan Selatan adalah seperti diagram alir berikut ini:.

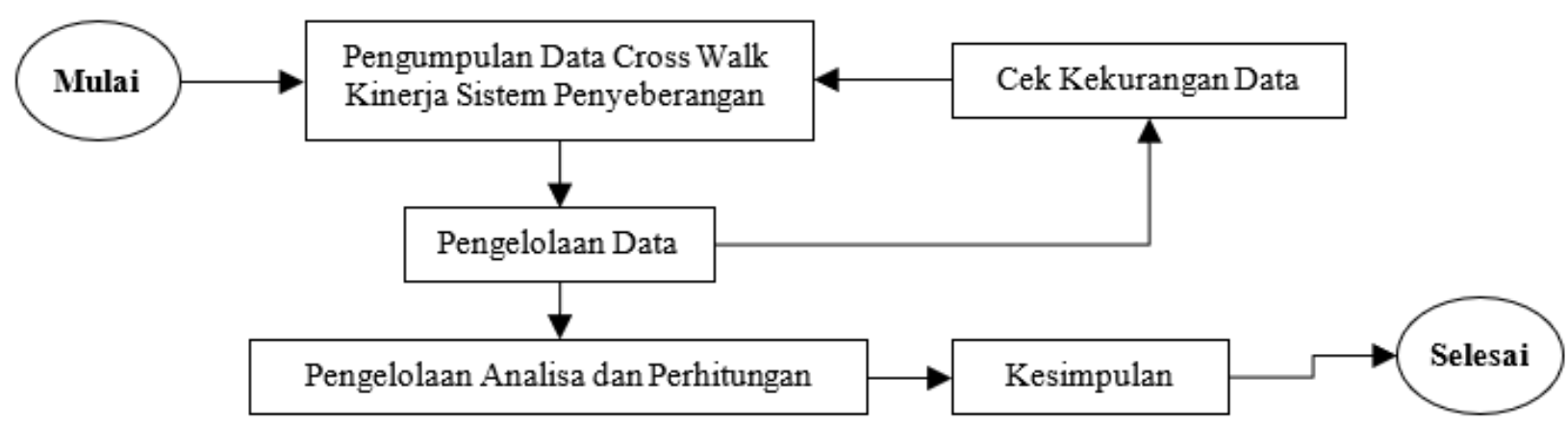

Gambar 4. Program Kerja Penelitian

\section{HASIL DAN PEMBAHASAN}

\section{Umum}

Proses pelayanan terjadi pada saat kendaraan antri masuk ke dalam kapal selama headway waktu keberangkatan kapal yang ditentukan. Tingkat occupancy kapal sangat dipengaruhi oleh laju kedatangan kendaraan dan proses pelayanan terhenti pada saat kapal bersandar di dermaga untuk menurunkan kendaraan dan ini tidak dipengaruhi oleh laju kedatangan kendaraan.

Bila laju kedatangan kendaraan tidak dapat diimbangi oleh laju pelayanan sistem penyeberangan yang ada, maka akan terjadi antrian yang sangat panjang yang mempengaruhi kapasitas lahan parkir dan akan menambah waktu tunggu kendaraan.

\section{Tingkat Kedatangan Kendaraan Roda 4}

Tingkat kedatangan $(\lambda)$ adalah banyaknya kendaraan yang datang atau memasuki areal pelabuhan untuk tujuan menyeberang per satuan waktu (menit). Dalam penelitian ini kedatangan kendaraan dicatat setiap satu menit selama $3 \times 24$ jam. 
Manajemen Operasional.., Hudan Rahmani ${ }^{(1)}$, Noor Jasmani ${ }^{(2)}$, Aminullah $^{(3)}$, Hendra Cahyadi ${ }^{(4)}$

Tabel 1. Tingkat Kedatangan Kendaraan dari tanggal 23 sampai 24 Desember 2021

\begin{tabular}{cccccc}
\hline Periode & $\lambda$ (kend/menit) & Periode & $\lambda$ (kend/menit) & Periode & $\lambda$ (kend/menit) \\
\hline $08.00-11.00$ & 0,283 & $08.00-11.00$ & 0,339 & $08.00-11.00$ & 0,244 \\
$11.00-14.00$ & 0,378 & $11.00-14.00$ & 0,383 & $11.00-14.00$ & 0,382 \\
$14.00-17.00$ & 0,372 & $14.00-17.00$ & 0,511 & $14.00-17.00$ & 0,599 \\
$17.00-20.00$ & 0,378 & $17.00-20.00$ & 0,428 & $17.00-20.00$ & 0,355 \\
$20.00-23.00$ & 0,361 & $20.00-23.00$ & 0,317 & $20.00-23.00$ & 0,467 \\
$23.00-02.00$ & 0,278 & $23.00-02.00$ & 0,300 & $23.00-02.00$ & 0,339 \\
$02.00-05.00$ & 0,183 & $02.00-05.00$ & 0,272 & $02.00-05.00$ & 0,044 \\
$05.00-08.00$ & 0,328 & $05.00-08.00$ & 0,317 & $05.00-08.00$ & 0,101 \\
\hline 24 jam & 0,320 & 24 jam & 0,358 & 24 jam & 0,317 \\
& $3 \times 24$ jam & & & 0,331 & \\
\hline
\end{tabular}

Waktu Rata-Rata Menurunkan Kendaraan

\section{Roda 4}

Waktu rata-rata menurunkan kendaraan roda 4 adalah untuk menentukan headway dermaga. Pengamatan kapal dengan tingkat occupancy minimal $50 \%$.

Perhitungan Waktu Rata-rata Menurunkan Kendaraan Roda 4

Nilai rata-rata sampel (X')

$$
\begin{aligned}
& X^{\prime}=\frac{\sum X i}{n}=\frac{9.21}{35}=0.263 \text { menit } / \text { kendaraan } \\
& \sigma=\sqrt{\frac{\sum\left(X_{i}-X^{2}\right)^{2}}{n-1}}=\sqrt{\frac{1,09559}{34}}=\sqrt{0,0322}=0,179
\end{aligned}
$$

$$
\begin{aligned}
\mathrm{KBA} & =\mathrm{X}^{\prime}+\mathrm{z}(1 / 2 \alpha) \cdot \alpha_{x} / \sqrt{\mathrm{n}} \\
& 0,263+1,96 \cdot 0,179 / \sqrt{35} \quad=0,32 \text { menit }
\end{aligned}
$$

$$
\begin{aligned}
\mathrm{KBA} & =\mathrm{X}^{\prime}+\mathrm{z}(1 / 2 \alpha) \cdot \alpha_{x} / \sqrt{\mathrm{n}} \\
& 0,263+1,96 \cdot 0,179 / \sqrt{35} \quad=0,20 \text { menit }
\end{aligned}
$$

Dimana:

BKA : Batas Kontrol Atas (upper limit)

BKA : Batas Kontrol Bawah (lower limit)

Jadi waktu menurunkan kendaraan yang mewakili adalah: 0,20-0,32 menit/ kendaraan.

\section{Waktu Rata-rata Menaikkan Kendaraan Roda 4}

Waktu Rata-rata Menaikkan Kendaraan Roda 4 ke dalam kapal sangat dipengaruhi oleh tingkat kedatangan kendaraan di pelabuhan dan faktor-faktor lainnya. Kegunaannya adalah untuk menentukan waktu bersandar minimum dan headway dermaga. Pengamatan kapal dengan tingkat occupancy minimum $50 \%$.
$\mathrm{X}^{\prime}=\frac{\sum \mathrm{Xi}}{\mathrm{n}}=\frac{54,25 \mathrm{C}}{36}=1.507$ menit/kendaraan

$\sigma=\sqrt{\frac{\sum(\mathrm{Xi}-\mathrm{X})^{2}}{\mathrm{n}-1}}=\sqrt{\frac{5,332164}{35}}=0,390$

Data diasumsikan berdistribusi normal dengan tingkat kepercayaan (level of significant) $5 \%$ dengan pengujian dua sisi (two tail test).

$$
\begin{aligned}
\mathrm{KBA}= & \mathrm{X}^{\prime}+\mathrm{z}(1 / 2 \alpha) \cdot \alpha_{x} / \sqrt{\mathrm{n}} \\
& 1,507+1,96 \cdot 0,390 / \sqrt{36}=1,634 \text { menit } \\
\mathrm{KBA} & =\mathrm{X}^{\prime}+\mathrm{z}\left(1 \frac{1}{2} \alpha\right) \cdot \alpha_{x} / \sqrt{\mathrm{n}} \\
& 0,507+1,96 \cdot 0,390 / \sqrt{36}=1,380 \text { menit }
\end{aligned}
$$

Jadi waktu kenaikan kendaraan yang mewakili adalah: 1,380 - 1,643 menit/kendaraan.

\section{Analisis Pelayanan Sistem Penyeberangan}

Headway dermaga adalah waktu minimum yang dibutuhkan untuk kapal berikutnya dapat bersandar pada dermaga yang sama dengan aman tanpa mengganggu kinerja sistem yang ada, sehingga besarnya headway dermaga $(\mathrm{Hw})$ dapat ditentukan sebagai berikut:

$\mathrm{H}_{\mathrm{w}}>\mathrm{T}_{\mathrm{s}}+\mathrm{T}_{\mathrm{p}}$

$\mathrm{T}_{\mathrm{p}}=\mathrm{T}_{\mathrm{r}}+\mathrm{T}_{\mathrm{d}}$ dan $\mathrm{T}_{\mathrm{s}}=\mathrm{T}_{\mathrm{t}}+\mathrm{T}_{\mathrm{m}}$

Dimana:

$\mathrm{T}_{\mathrm{s}}=$ Waktu bersandar kapal

$\mathrm{T}_{\mathrm{r}}=$ Waktu berputar kapal

$\mathrm{T}_{\mathrm{d}}=$ Waktu persiapan bongkar kapal

$\mathrm{Tt}=$ Waktu rata-rata menurunkan kendaraan

$\mathrm{Tm}=$ Waktu rata-rata menaikkan kendaraan

$\mathrm{Tp}=$ Waktu maneuver/putar

Berdasarkan hasil analisis data menurunkan dan menaikkan kendaraan dari/ke dalam kapal, maka headway dermaga $(\mathrm{Hw})$ untuk kondisi tertentu dapat ditentukan seperti pada tabel 2 berikut 
Tabel 2 Perhitungan Headway

\begin{tabular}{|c|c|c|c|c|c|c|c|c|}
\hline \multirow{2}{*}{ Batas } & \multicolumn{2}{|c|}{$\begin{array}{c}\text { Waktu Pelayanan } \\
\text { Kapal }\end{array}$} & \multicolumn{2}{|c|}{$\begin{array}{c}\text { Kap. Kapal } \\
(\mathrm{Qk}=18 \text { kend })\end{array}$} & \multirow{2}{*}{$\begin{array}{c}\text { Waktu } \\
\text { Sandar } \\
\mathrm{T}_{\mathrm{S}}(\mathrm{Mnt})\end{array}$} & \multicolumn{2}{|c|}{ Waktu Manuver } & \multirow{2}{*}{$\begin{array}{l}\text { Headway } \\
\text { Hw (Mnt) }\end{array}$} \\
\hline & $\begin{array}{c}\text { Muat (qm) } \\
\text { mnt/kend }\end{array}$ & $\begin{array}{c}\text { Turun } \\
\text { mnt/kend }\end{array}$ & $\begin{array}{c}\mathrm{T}_{\mathrm{m}} \\
\text { (mnt) }\end{array}$ & $\begin{array}{c}\mathrm{T}_{\mathrm{t}} \\
(\mathrm{mnt})\end{array}$ & & $\begin{array}{c}\mathrm{T}_{\mathrm{r}} \\
\text { (mnt) }\end{array}$ & $\begin{array}{c}\mathrm{T}_{\mathrm{d}} \\
(\mathrm{mnt})\end{array}$ & \\
\hline $\mathrm{BB}$ & 1,38 & 0,20 & 24,84 & 3,60 & 28,44 & 3,59 & 1,78 & 33,81 \\
\hline Rata-rata & 1,51 & 0,26 & 27,09 & 4,68 & 31,77 & 4,33 & 2,02 & 38,12 \\
\hline BA & 1,63 & 0,32 & 29,34 & 5,76 & 35,10 & 5,10 & 2,25 & 42,42 \\
\hline
\end{tabular}

Keterangan:

Kapasitas kapal rata-rata $(\mathrm{Qk})=18$ kendaraan

Tabel 3 Perhitungan Waktu Siklus (Tc) di Pelabuhan Batulicin

\begin{tabular}{llllllll}
\hline Batas & $\begin{array}{l}\text { Waktu } \\
\text { Sandar } \\
(\text { Ts) } \\
\text { (menit) }\end{array}$ & $\begin{array}{l}\text { Waktu } \\
\text { Manuver } \\
\text { (menit) }\end{array}$ & $\begin{array}{l}\text { Waktu } \\
\text { Batulicin - Tanjung } \\
\text { Serdang (menit) }\end{array}$ & $\begin{array}{l}\text { Waktu } \\
\text { Tanjung } \\
\text { Batulicin (menit) }\end{array}$ & $\begin{array}{l}\text { Layar } \\
\text { (maktuang }\end{array}$ & $\begin{array}{l}\text { Waklus } \\
\text { (Tc) } \\
\text { (menit) }\end{array}$ & $\begin{array}{l}\text { Jumlah } \\
\text { Kapal (N) }\end{array}$ \\
\hline BB & 28,44 & 5,37 & 36,04 & 39,50 & 109,36 & 3 \\
Rata-rata & 31,77 & 6,35 & 37,12 & 39,56 & 114,80 & 3 \\
BA & 35,10 & 7,32 & 38,20 & 39,62 & 120,24 & 3 \\
\hline
\end{tabular}

Bardasarkan kondisi lapangan waktu berlayar satu arah Batulicin - Tanjung Serdang $\left.\left(\mathrm{T}_{1} 1\right)\right)$ dan Tanjung Serdang - Batulicin $\left(\mathrm{T}_{1} 2_{2}\right)$ dan waktu maneuver $\left(\mathrm{T}_{\mathrm{p}}\right)$, maka waktu siklus dapat dihitung sebagai berikut:

\section{Perhitungan Biaya Waktu Tunggu Kedatangan Kendaraan Roda 4}

Biaya waktu tunggu adalah biaya yang harus ditanggung oleh pengguna jasa sebagai opportunity cost yang hilang akibat dari tertundanya pelayanan yang dibutuhkan, sehingga pengguna jasa terpaksa harus menunggu/antri. Jumlah waktu tunggu tersebut dikonversikan kedalam biaya finansial berdasarkan jenis kendaraan, maksud perjalanan dan jenis barang/komoditi serta volume yang diangkut. Biaya waktu tunggu kendaraan roda 4 dihitung berdasarkan jumlah waktu tunggu dikalikan dengan biaya tunggu persatuan waktu untuk masing-masing jenis kendaraan. Analisis dilakukan dari data sebelumnya dan jumlah waktu tunggu sangat ditentukan headway keberangkatan kapal atau jumlah operasi kapal per hari dan kapasitas kapal.

Biaya Waktu tunggu kendaraan roda 4 yaitu truck, bus dan sejenis Toyota Avanza/ sedan diperhitungkan terdiri dari: a. Biaya Kendaraan/Biaya Bunga Bank per jam (I)

$$
\begin{array}{ll}
\mathrm{I}=\frac{(\mathrm{EC}-\mathrm{SC}) . \mathrm{I}}{\mathrm{Wh}_{\mathrm{h}}} \\
\mathrm{D}=\frac{\mathrm{R}(1+\mathrm{R})^{\mathrm{S}}}{(1+\mathrm{R})^{\mathrm{N}}-1} \\
\text { Dimana: } & \\
\mathrm{EC}= & \text { Nilai ekonomi mobil } \\
\mathrm{SC}= & \text { Nilai sisa }(10 \% \text { EC }) \\
\mathrm{R}= & \text { Suku bunga bank }=20 \% \text { per } \\
\text { tahun } & \\
\mathrm{N}= & \text { Umur ekonomi } \\
\mathrm{D}= & \text { Faktor pengembalian modal } \\
\mathrm{Wh} & =\quad \text { Jam kerja efektif }
\end{array}
$$

b. Biaya Barang per jam (Commodity of Cost $=\mathrm{COC}$ ) untuk kendaraan truck

$$
\mathrm{COC}=\frac{\text { Hartaper ton } \times \text { Total Berat } \times \mathrm{R}}{\text { Wh }}
$$

c. Biaya Awak Kendaraan (BAK) per jam (supir dan kernet) untuk truck dan bus.

Total Biaya $=(\mathrm{I})+(\mathrm{COC})+(\mathrm{BAK})$ 
Manajemen Operasional.., Hudan Rahmani ${ }^{()}$, Noor Jasmani ${ }^{(2)}$, Aminullah $^{(3)}$, Hendra Cahyadi ${ }^{(4)}$

Tabel 4. Biaya Waktu Tunggu Kendaraan Roda 4

\begin{tabular}{cccccc}
\hline $\begin{array}{c}\text { Type } \\
\text { Kendaraan }\end{array}$ & $\begin{array}{c}\text { Harga Ekonomis } \\
\text { (EC) (Rp) }\end{array}$ & $\begin{array}{c}\text { Bunga } \\
\text { Bank (R) }\end{array}$ & $\begin{array}{c}\text { Faktor } \\
\text { Pengembalian } \\
\text { Modal (D) }\end{array}$ & $\begin{array}{c}\text { Jam Kerja Efektif } \\
\text { (jam/tahun) (Wh) }\end{array}$ & $\begin{array}{c}\text { Pengembalian } \\
\text { Modal per jam (Rp) }\end{array}$ \\
\hline Truck & $315.000 .000,-$ & 20 & 0.277 & 1.300 & $60.407,31$ \\
Bus & $700.000 .000,-$ & 20 & 0.277 & 1.800 & $96.950,00$ \\
Mobil & $230.000 .000,-$ & 20 & 0.239 & 760 & $75.446,05$ \\
Pribadi & & & & & \\
\hline
\end{tabular}

Tabel 5. Biaya Waktu Tunggu Barang (commodity cost)/jam

\begin{tabular}{ccccc}
\hline $\begin{array}{c}\text { Total Berat } \\
\text { Komoditi } \\
\text { (ton) }\end{array}$ & $\begin{array}{c}\text { Harga Komoditi per } \\
\text { ton } \\
(\mathrm{Rp})\end{array}$ & $\begin{array}{c}\text { Bunga } \\
\text { Bank } \\
(\%)\end{array}$ & $\begin{array}{c}\text { Jam Kerja Efektif } \\
\text { (jam/tahun) }\end{array}$ & $\begin{array}{c}\text { Harga } \\
\text { Komoditi } \\
\text { per jam }\end{array}$ \\
\hline 7 & $15.000 .000,-$ & 20 & 1.300 & 16.154 \\
\hline
\end{tabular}

Tabel 6. Biaya Waktu Tunggu Penumpang (passengers cost)/jam

\begin{tabular}{llll}
\hline & $\begin{array}{l}\text { Jumlah Penumpang } \\
\text { Rata-rata }\end{array}$ & $\begin{array}{l}\text { Pendapatan per jam } \\
(\mathrm{Rp})\end{array}$ & Biaya Total per Kendaraan per jam (Rp) \\
\hline Truck & 2.08 & 11.250 & 23.400 \\
Bus & 22.02 & 9.750 & $195.195,00$ \\
Mobil Pribadi & 3.05 & 14.000 & $42.700,00$ \\
\hline
\end{tabular}

Tabel 7. Rekapitulasi Biaya Waktu Tunggu Kendaraan Roda 4/jam

\begin{tabular}{cccc}
\hline \multirow{2}{*}{ Komponen Biaya } & \multicolumn{3}{c}{ Jenis Kendaraan (Rp)/jam } \\
\cline { 2 - 4 } & Truck & Bis & Mobil Penumpang \\
\hline Kendaraan & $60.407,31$ & $96.950,00$ & $75.446,05$ \\
Barang & 16.154 & - & - \\
Penumpang & $23.400,00$ & $195.195,00$ & $42.700,00$ \\
Total Biaya & $83.807,31$ & 292.145 & $118.146,05$ \\
\hline
\end{tabular}

Tabel 8 Biaya Gabungan Berdasarkan Kedatangan Kendaraan dan Headway Kapal

\begin{tabular}{ccccccccc}
\hline $\begin{array}{c}\text { Jumlah } \\
\text { Kapal } \\
\text { NK } \\
\text { (buah) }\end{array}$ & $\begin{array}{c}\text { Headway } \\
\text { Kapal } \\
\text { HK } \\
\text { (menit) }\end{array}$ & $\begin{array}{c}\text { Waktu } \\
\text { Buka } \\
\text { Pintu } \\
\text { Tm } \\
\text { (menit) }\end{array}$ & $\begin{array}{c}\text { Waktu } \\
\text { Pintu } \\
\text { Tt } \\
\text { (menit) }\end{array}$ & $\begin{array}{c}\text { Panjang } \\
\text { Antrian } \\
\text { NST } \\
\text { (buah) }\end{array}$ & $\begin{array}{c}\text { Waktu } \\
\text { Tunggu } \\
\text { (jam/kedtg. } \\
\text { kpl) }\end{array}$ & $\begin{array}{c}\text { Biaya Tunggu } \\
\text { (Rp/kedtg. } \\
\text { kpl) }\end{array}$ & $\begin{array}{c}\text { Biaya } \\
\text { Kapal } \\
\text { (Rp/kedtg) }\end{array}$ & $\begin{array}{c}\text { Biaya Gab. } \\
\text { (Rp) }\end{array}$ \\
\hline 1 & 2 & 3 & 4 & 5 & 6 & 7 & 8 & 9 \\
2 & 41,34 & 4,49 & 36,85 & 38,58 & 13,29 & $33.458 .571,75$ & 5161500 & $38.620 .071,75$ \\
3 & 33,07 & 4,49 & 28,58 & 30,86 & 8,50 & $17.218 .206,41$ & 6451875 & 23.670 .081 .41 \\
4 & 27,56 & 4,49 & 23,07 & 24,04 & 5,91 & $6.559 .505,64$ & 7742250 & 14.301 .755 .64 \\
5 & 23,62 & 4,49 & 19,13 & 22,05 & 4,34 & $6.182 .768,34$ & 9032625 & 15.215 .393 .34 \\
6 & 20,67 & 4,49 & 16,18 & 19,29 & 3,32 & $4.026 .379,80$ & 10323000 & 14.349 .379 .80 \\
\hline
\end{tabular}

Perhitungan Jumlah Dermaga

Jumlah kedatangan kendaraan $(\mathrm{Vv})=36 \mathrm{kend} / \mathrm{jam}$

Kapasitas kapal $(\mathrm{Qk})=18 \mathrm{kend} / \mathrm{buah}$

Waktu tambat $(\mathrm{Ts})=31,77$ menit $=0,53$ jam

Waktu siklus $(\mathrm{Tc})=114,8$ menit $=1,93 \mathrm{jam}$
Jumlah keberangkatan kapal $(\mathrm{Jk})=\frac{\mathrm{Vv}}{\mathrm{Qk}}=\frac{36}{1 \mathrm{R}}=2$ trip/jam

Headway kapal (hw) $=\frac{1}{\pi}=\frac{1}{2}=0,50 \mathrm{jam}$

Jumlah dermaga $(\mathrm{JD})=\underline{\underline{T_{s}}} \frac{0,53}{=0,50}=1,06$ buah $\sim 1$ buah 


\section{Perhitungan Jumlah Kapal}

- Perhitungan jumlah kapal minimum berdasarkan panjang antrian maximum adalah didapat dari Gambar 4.2. Dengan panjang antrian maximum 20 unit kendaraan maka didapat jumlah dermaga kapal minimum 1 buah.

- Perhitungan jumlah kapal maximum didapat dengan jumlah dermaga maksimum 1 buah.

$$
\mathrm{JD}=\stackrel{\frac{\mathrm{T}_{5}}{\mathrm{H}_{\mathrm{w}}}}{\rightarrow} \rightarrow 1=\stackrel{\frac{0,53}{\mathrm{Hw}}}{\rightarrow} \mathrm{H}_{\mathrm{w}}=0,53 \mathrm{jam}
$$

Kapal maksimum $\left(\mathrm{N}_{\max }\right)=\frac{\mathrm{T}_{\bar{c}}}{\mathrm{H}_{w}}=\frac{0,91}{0,53}=3,82 \sim 4$ buah

Maka jumlah kapal yang dioperasikan untuk menunjang kinerja optimal adalah 4 buah kapal.

\section{Pembahasan}

Dari grafik biaya gabungan untuk jumlah kedatangan kendaraan tertentu dapat diketahui bahwa jumlah kapal yang paling efisien (optimal) adalah berdasarkan total biaya gabungan yang minimum.

Untuk kasus dalam penelitian ini adalah:

a. Sistem operasi/jadwal yang ditetapkan pada jumlah kedatangan kendaraan maksimum adalah:

- Waktu siklus (Tc): 114,5 menit

- Jumlah kapal (N): 4 buah

- Headway keberangkatan kapal (hw): 30 menit

- Kedatangan kendaraan roda-4: 36 kend/jam

- Panjang antrian: 20 kend

Berdasarkan analitis biaya gabungan minimum menunjukkan sistem operasi yang ditetapkan belum mendekati optimum. b. Sistem operasi/jadwal yang ditetapkan pada kondisi puncak dengan melihat dari kondisi areal parkir yang ada, dengan asumsi panjang antrian 20 kendaraan, diperlukan jumlah kapal optimal sebanyak 4 Buah

\section{KESIMPULAN}

Berdasarkan perhitungan biaya gabungan dengan jumlah dermaga 1 buah dan kapasitas kapal rata-rata $(\mathrm{Qk}): 18$ unit kendaraan sistem pelayanan yang optimum dapat ditentukan sebagai berikut:

a. Kedatangan kendaraan: 36 unit/jam, terjadi kekurangan pelayanan dengan panjang antrian 20 kendaraan, Headway kapal (hw) : 30 menit

b. Berdasarkan biaya gabungan kondisi yang optimal adalah sistem operasi dengan jumlah kapal $(\mathrm{N})$ : 4 buah

c. Dermaga masih layak sebanyak 1 (satu) buah

\section{DAFTAR PUSTAKA}

Kanafani, Adib, (1983), Transportation Demand Analysis, Mc. Graw-Hill Book Company.

Kodoatie, Robert J, (1997), Analisa Ekonomi Teknik, Cetakan Kedua, Andi Offset, Yogyakarta.

Morlok, Edward K, (1995), Pengantar Teknik dan Perencanaan Transportasi, ed; Yani Sianipar, Erlangga, Jakarta.

Nasution, H.M.N, (1996), Manajemen Transportasi, Ghalia Indonesia, Jakarta.

Soerjatmodjo, Gatot (2001), Studi Optimasi Sistem operasi Pelabuhan Penyeberangan Padangbai - Pulau Bali, Tesis, Institut Teknologi Sepuluh Nopember, Surabaya.

Tamin, OZ, (1997), Perencanaan dan Pemodelan Transportasi, Penerbit ITB, Bandung. 